\title{
Molecular detection of Apicomplexa protozoa in tissues from Alouatta guariba clamitans ${ }^{1}$
}

\author{
Aline Ludwig ${ }^{2 *}$ (D) , Laurete Murer ${ }^{3}$ (D) , Helton F. dos Santos ${ }^{3}$, Adriana Ludwig', \\ Luis Antonio Sangioni ${ }^{2}$ and Fernanda S.F. Vogel $^{2}$
}

\begin{abstract}
Ludwig A., Murer L., dos Santos H.F., Ludwig A., Sangioni L.A. \& Vogel F.S.F. 2021. Molecular detection of Apicomplexa protozoa in tissues from Alouatta guariba clamitans. Pesquisa Veterinária Brasileira 41:e06717, 2021. Laboratório de Doenças Parasitárias, Departamento de Medicina Veterinária Preventiva, Universidade Federal de Santa Maria, Av. Roraima 1000, Prédio 63C, Santa Maria, RS 97105-900, Brazil. E-mail: lineludwig09@gmail.com

The brown howler monkey (Alouatta guariba clamitans) is a primate species widely distributed in South America. Infections by protozoa are common in primates. However, studies on protozoa in primates in Brazil are scarce, so the goal of this study was to investigate DNA from the apicomplexan protozoa Neospora caninum, Sarcocystis spp. and Toxoplasma gondii in tissues of A. guariba clamitans. DNA extraction was performed on tissue samples from the heart, brain, liver, spleen, lung and intestine of six A. guariba clamitans from Santa Maria, Central Region of Rio Grande do Sul, Brazil. Conventional PCR was performed using 18S rRNA gene general primers for Apicomplexa and also specific primers to amplify Neospora spp. and Toxoplasma gondii DNA. All animals were positive in the 18S PCR and the genetic sequencing confirmed the presence of Sarcocystis spp. DNA in the tissues of four animals belonging to at least two species (S. neurona and S. gigantea) and T. gondii DNA in the other two animals. One positive sample for T. gondii was genotypically characterized as atypical by the restriction fragment length polymorphism technique. $N$. caninum DNA was not detected in the tested samples. The presence of Apicomplexa protozoan DNA in the tissues of the six animals tested in this study highlights the importance of howler monkeys as maintainers of these pathogens in nature.
\end{abstract}

INDEX TERMS: Molecular detection, Apicomplexa, protozoa, Alouatta guariba clamitans, brown howler monkey, Sarcocystis, Toxoplasma, genotyping, wildlife animals.

RESUMO.- [Detecção molecular de protozoários Apicomplexa em tecidos de Alouatta guariba clamitans.] 0 bugio ruivo (Alouatta guariba clamitans) é uma espécie de primata amplamente distribuída na América do Sul. As infecções por protozoários são comuns em primatas. Entretanto, estudos

\footnotetext{
${ }^{1}$ Received on October 27, 2020.

Accepted for publication on December 9, 2020.

${ }^{2}$ Laboratório de Doenças Parasitárias, Departamento de Medicina Veterinária Preventiva, Universidade Federal de Santa Maria (UFSM), Av. Roraima 1000, Prédio 63C, Santa Maria, RS 97105-900, Brazil. *Corresponding author: lineludwig09@gmail.com

${ }^{3}$ Núcleo de Estudos e Pesquisas em Animais Silvestres, Laboratório Central de Diagnóstico de Patologias Aviárias, Departamento de Medicina Veterinária Preventiva, Universidade Federal de Santa Maria (UFSM), Av. Roraima 1000, Prédio 63C, Santa Maria, RS 97105-900, Brazil.

${ }^{4}$ Laboratório de Ciências e Tecnologias Aplicadas em Saúde, Instituto Carlos Chagas (ICC), Fundação Oswaldo Cruz (Fiocruz), Rua Prof. Algacyr Munhoz Mader 3775, Curitiba, PR 81350-010, Brazil.
}

sobre protozoários em primatas no Brasil são escassos, portanto o objetivo deste estudo foi pesquisar DNA dos protozoários Apicomplexa Neospora caninum, Sarcocystis spp. e Toxoplasma gondii em tecidos de A. guariba clamitans. A extração de DNA foi realizada em amostras de tecido do coração, cérebro, fígado, baço, pulmão e intestino de seis A. guariba clamitans oriundos de Santa Maria, Região Central do Rio Grande do Sul, Brasil. Foi realizada PCR convencional utilizando primers geral do gene 18S rRNA para Apicomplexa e também primers específicos para amplificação de DNA de Neospora spp.e Toxoplasma gondii. Todos os animais foram positivos no PCR geral para Apicomplexa e no sequenciamento genético confirmou-se a presença de DNA de Sarcocystis nos tecidos de quatro animais pertencentes a pelo menos duas espécies (S. neurona e S. gigantea), e DNA de T. gondii foi detectado nos outros dois animais. Uma amostra positiva para T. gondii foi caracterizada genotipicamente como atípico pela técnica 
de polimorfismo do comprimento do fragmento de restrição. Não foi detectado DNA de $N$. caninum nas amostras testadas. A presença de DNA de protozoários apicomplexa nos tecidos dos seis animais testados neste estudo destaca a importância dos bugios ruivos como mantenedores desses patógenos na natureza.

TERMOS DE INDEXAÇÃO: Detecção molecular, protozoários, Apicomplexa, Alouatta guariba clamitans, bugio ruivo, Sarcocystis, Toxoplasma, genotipagem, animais selvagens.

\section{INTRODUCTION}

The Apicomplexa phylum comprises several genera of pathogenic parasites (Adl et al. 2007), such as Toxoplasma gondii, Neospora caninum, and Sarcocystis spp. These apicomplexan parasites have a heteroxenous life cycle infecting multiple hosts and their transmission is facilitated by predator-prey relationships. In the intermediate hosts (often herbivorous or omnivorous), infectious stages are formed by tissue cysts that can be ingested by the definitive host (usually a carnivorous predator) (Sibley 2003).

Protozoal infections in nonhuman primates are common and native populations of primates host an amazing diversity of parasites and infectious agents, reinforcing the role of wild animals as reservoirs for zoonosis (Nunn \& Altizer 2005, Silva et al. 2006).

Primates from genus Alouatta are the most widely distributed New World monkeys and Alouatta guariba clamitans (brown howler monkey) is endemic in the Atlantic Forest in Brazil and Argentina (Meireles et al. 1999). Because of this wide distribution, howler monkeys are a potential parasite carrier of great zoonotic importance.

There are few studies on endoparasites in primates in Brazil. Therefore, this study aimed to evaluate the presence of T. gondii, Sarcocystis spp., and N. caninum DNA in different tissues of $A$. guariba clamitans, to further knowledge regarding protozoan infection in local primates.

\section{MATERIALS AND METHODS}

Samples. Tissue samples of brown howler monkeys (Alouatta guariba clamitans) were obtained from dead animals sent for necropsy at the "Núcleo de Estudos e Pesquisas em Animals Silvestres" from the "Laboratório Central de Diagnóstico de Patologias Aviárias", "Universidade Federal de Santa Maria". All animals came from a wild fauna maintainer located near the city Santa Maria (2941'52.2"S $53^{\circ} 55^{\prime} 11.0^{\prime \prime}$ ), in the Central Region of Rio Grande do Sul State, Southern region of Brazil. The animals died at different times and there is no information about the place of birth, the time they lived in the reserve, clinical signs, or previous health conditions. Samples from the brain, heart, liver, lung, spleen, and intestine $(n=35$, since the brain of one animal was not provided) were collected and stored at $-20^{\circ} \mathrm{C}$ until processed.

DNA extraction. A total of 20 to $50 \mathrm{mg}$ of collected tissues was macerated for DNA extraction using the Wizard Genomic DNA Purification kit (Promega, Madison/WI USA), following the instructions of the manufacturer with modification in the lysis step (carried out overnight at $55^{\circ} \mathrm{C}$ ) according to a previous report (Moré et al. 2011). Conventional polymerase chain reaction (PCR) was performed for molecular detection of DNA from each protozoan.
Molecular detection of Toxoplasma gondii. T. gondii DNA detection was performed using a $529 \mathrm{bp}$ genetic marker that repeats approximately 300 times in the T. gondii genome, consequently showing high sensitivity (Homan et al. 2000). The primers used were: forward (Tox4) 5'-CGCTGCAGGGAGGAAGACGAAAGTTG-3' and reverse (Tox5) 5'-CGCTGCAGACACAGTGCATCTGGATT-3'. The reaction was run in a final volume of $25 \mu \mathrm{l}$ mixture containing $2.5 \mu \mathrm{l} 10 \mathrm{x}$ PCR Buffer with $\mathrm{MgCl}_{2}, 10 \mathrm{mM}$ dNTP, $10 \mathrm{pmol}$ of each primer, 0.7U JumpStart Taq DNA Polymerase (Sigma Aldrich, St. Louis/MO, USA), and 100ng DNA. DNA from T. gondii (RH strain) and ultrapure water were used as positive and negative controls, respectively. Amplification was conducted in a thermal bath with initial denaturation for $5 \mathrm{~min}$ at $94^{\circ} \mathrm{C}$, followed by 35 cycles of $30 \mathrm{~s}$ at $95^{\circ} \mathrm{C}, 1 \mathrm{~min}$ at $55^{\circ} \mathrm{C}, 1 \mathrm{~min}$ at $72^{\circ} \mathrm{C}$ and a final extension of $5 \mathrm{~min}$ at $72^{\circ} \mathrm{C}$. Amplification products were visualized in a transilluminator after $1.5 \%$ agarose gel electrophoresis using gel red as a DNA dye.

Toxoplasma gondii genotype was determined by restriction fragment length polymorphism (PCR-RFLP) using six genetic markers, SAG1, SAG3, BTUB, GRA6, L358, and PK1, as previously described (Su et al. 2006, Su et al. 2010). DNA target sequences were first amplified by PCR multiplex using external primers of all markers, followed by a nested PCR using internal primers individually for each marker. The nested PCR products were then cleaved by restriction enzymes under specific temperature and time conditions. The primer sequences and enzymes are described in a previous study (Su et al. 2010). Positive controls of type I (GTI), II (PTG), and III (CTG) strains were used in the reactions. Further, samples were subjected to $2.5-3 \%$ agarose gel electrophoresis and were visualized using an ultraviolet light transilluminator. The images were compared with controls for genotype determination.

Molecular detection of Neospora caninum. PCR was performed using a primer set for specific amplification of the $N$. caninum Nc-5 gene: forward (Np21), 5'-CCCAGTGCGTCCAATCCTGTAAC-3'; and reverse (Np6), 5'-CTCGCCAGTCAACCTACGTCTTCT-3' with a 328bp expected product according to Yamage et al. (1996). The reaction was conducted in $25 \mu$ l final volume using $0.7 \mathrm{U}$ JumpStart Taq DNA Polymerase (Sigma Aldrich, St. Louis/MO, USA); 2.5 $\mu$ l 10x PCR Buffer with $\mathrm{MgCl}_{2} ; 5 \mathrm{pmol}$ from each primer, $6 \mathrm{mM}$ dNTPs, and 50 ng template DNA. For amplification of the genetic material in a thermal cycler, a protocol was performed using 35 cycles, with initial denaturation at $95^{\circ} \mathrm{C}$ for $5 \mathrm{~min}$, denaturation at $95^{\circ} \mathrm{C}$ for $1 \mathrm{~min}$, annealing at $50^{\circ} \mathrm{C}$ for $1 \mathrm{~min}$, extension at $72^{\circ} \mathrm{C}$ for $1 \mathrm{~min}$, followed by a final extension at $72^{\circ} \mathrm{C}$ for $10 \mathrm{~min}$. Amplification products were visualized in a transilluminator after $1.5 \%$ agarose gel electrophoresis. DNA from $N$. caninum NC1 and ultrapure water were used as positive and negative controls, respectively.

Amplification and sequencing of apicomplexan 18S rRNA. The presence of Sarcocystis spp. and potentially other apicomplexans were detected by amplification of 18 S ribosomal RNA gene (18S rRNA). Nested PCR of 18S rRNA was performed using the general primers for Apicomplexa, external primers $\mathrm{Tg} 18 \mathrm{~s} 48 \mathrm{~F}$ ( $5^{\prime}$-CCATGCATGTCTAAGTATAAGC-3') and Tg18s359R (5'-GTTACCCGTCACTGCCAC-3'), and internal primers Tg18s58F (5'-CTAAGTATAAGCTTTTATACGGC-3') and Tg18s348R (5'-TGCCACGGTAGTCCAATAC-3') (Silva et al. 2009). The PCR mix contained $25 \mathrm{mM}$ of external primers or $50 \mathrm{mM}$ of internal primers. It also contained $0.7 \mathrm{U}$ JumpStart Taq DNA Polymerase: $2.5 \mu \mathrm{l} 10 \mathrm{x}$ PCR Buffer with $\mathrm{MgCl}_{2}, 10 \mathrm{mM}$ dNTP, and 50ng DNA. Amplifications were conducted with initial denaturation for $5 \mathrm{~min}$ at $94^{\circ} \mathrm{C}$, followed by 35 cycles of $45 \mathrm{~s}$ at $94^{\circ} \mathrm{C}, 45 \mathrm{~s}$ at $55^{\circ} \mathrm{C}, 45 \mathrm{~s}$ at $72^{\circ} \mathrm{C}$ and a final extension of $3 \mathrm{~min}$ at $72^{\circ} \mathrm{C}$. Amplification products were visualized in a transilluminator after $1.5 \%$ agarose gel electrophoresis. 
Amplification can generate distinct amplicon sizes, such as about 290 bp product for Sarcocystis neurona, N. caninum, Hammondia hammondi, and T. gondii, and 310bp for other Sarcocystis spp. As this test is not species-specific, the nested PCR amplicons were subjected to sequencing for genus confirmation. The amplified DNA product was purified using the QIAquick PCR Purification Kit (Qiagen, Hilden, Germany) according to the manufacturer's instructions and subjected to DNA sequencing by ACTGene - Sequencing Service (Alvorada/RS, Brazil) with internal forward and reverse primers. The sequences obtained were filtered by quality using Staden Package (Staden et al. 2000), and the identity of the sequences was confirmed using blastn (Johnson et al. 2008) comparing to the Genbank nucleotide collection. Sequences identified as Sarcocystis spp. were aligned using MUSCLE (Edgar 2004) and the alignment was visualized in Genedoc 2.7 (Nicholas et al. 1997).

\section{RESULTS AND DISCUSSION}

The most common parasite found in New World primates are nematodes, followed by protozoa. Among primates, Alouatta is one of the most studied genera, although parasitological knowledge is still limited. Therefore, parasitological screenings, both by morphological and molecular analysis, are crucial to improve our understanding in this field (Solórzano-García \& Pérez-Ponce de León 2018). In this study, we performed molecular detection of three protozoan genera in six different tissues from six brown howler monkeys. By macroscopic analysis during necropsy no significant lesions were found, so it was not possible to define the causes of the death of the animals. However, in all animals, DNA was detected in at least one of the protozoa, indicating that the brown howler monkeys in the region served as parasite reservoirs. The PCR results are shown in Table 1 , and the genetic sequencing analysis is shown in Table 2.
Neospora caninum DNA was not detected in any of the samples tested in this study. There is little information in the literature regarding the occurrence and importance of $N$. caninum in primates. However, experimental infection in nonhuman primates by Neospora has been confirmed (Barr et al. 1994, Ho et al. 1997), and a case of natural infection in Night Monkey (Aotus azarae infulatus) has been reported (Costa et al. 2018). The differential diagnosis is relevant because of the similarity of tachyzoites, the close phylogenetic relationship between T. gondii and N. caninum (Dubey \& Lindsay 1996), and the lack of information of the consequences of neosporosis in primates.

Toxoplasma gondii DNA was found in one animal (Animal 4) with the specific primers and in two (Animals 4 and 5) with the 18S rRNA marker. The identity of T. gondii sequences was confirmed using blastn. Although both genes are repeated in the genome, differences in amplification sensitivity among primers are expected if a low amount of parasite DNA is present in the sample (Jones et al. 2000, Cresti et al. 2001).

Toxoplasma gondii is widespread in the world, affecting humans and many warm-blooded animals (Dubey 1986). In this study, this parasite was found in two brown howler monkeys. New World Monkeys, such as howler monkeys, are very susceptible to toxoplasmosis (Nery-Guimarães \& Franken 1971, Molina et al. 2014, Santos et al. 2014), and the disease is often acute and fatal (Epiphanio et al. 2003). The presence of infected herbivores indicates environmental contamination by oocysts. In the natural environment, wild felids (definitive hosts) cohabit with other animals and may spread T. gondii to the wild population (Dubey \& Jones 2008).

Toxoplasma gondii genotypic analysis of Animal 4 suggested an atypical genotype because different markers indicated distinct genotypes: SAG1 = type 1; SAG3 = type 1; PK1 = type $1 ; \mathrm{BTUB}=$ type $1 ; \mathrm{GRA} 6=$ type $1 ; \mathrm{L} 358=$ type 3 . This finding is

Table 1. Results of PCR for detection of Toxoplasma gondii marker and 18S rRNA gene in different tissues of six specimens of brown howler monkey (Alouatta guariba clamitans)

\begin{tabular}{ccccccccccccc}
\hline \multirow{2}{*}{ Animals } & \multicolumn{9}{c}{ T. gondii marker } & \multicolumn{9}{c}{ 18S rRNA gene } \\
\cline { 2 - 11 } & Heart & Brain & Liver & Spleen & Intestine & Lung & Heart & Brain & Liver & Spleen & Intestine & Lung \\
\hline 1 & - & - & - & - & - & - & + & + & + & + & - \\
2 & - & - & - & - & - & - & + & - & + & + \\
3 & - & - & - & - & - & - & - & + & + & + & - & + \\
4 & + & NA & + & - & - & + & + & NA & + & + & + & + \\
5 & - & - & - & - & - & - & + & + & - & - & + \\
6 & - & - & - & - & - & - & - & + & - & - & + & +
\end{tabular}

Results are indicated with + for positive amplification and - for absence of amplification; NA = tissue not available.

Table 2. Result of blastn searches of sequenced samples of six specimens of brown howler monkey (Alouatta guariba clamitans) against the GenBank

\begin{tabular}{cccc}
\hline Animals/Sample* & ID & Species & Coverage/Identity (\%) \\
\hline 1/brain & MK420020.1 & Sarcocystis gigantea isolate OS13 & $100 / 99.4$ \\
2/heart & MK420020.1 & Sarcocystis gigantea isolate OS13 & $100 / 99.4$ \\
3/brain & MK420020.1 & Sarcocystis gigantea isolate OS13 & $100 / 99.4$ \\
4/heart & KX008033.1 & Toxoplasma gondii isolate Tg10 & $100 / 100$ \\
5/heart & KX008033.1 & Toxoplasma gondii isolate Tg10 & $100 / 100$ \\
6/brain & AH009986.2 & Sarcocystis neurona & $100 / 99.3$
\end{tabular}

*For each sample, only the first blast hit result is shown with the sequence GenBank accession number (ID), the name of species, the coverage

(proportion of sequence aligned) and the percent identity of alignment. 
consistent with previous studies that show a large circulation of atypical genotypes in Brazil, different from those found in North America and Europe (Pena et al. 2008, Dubey \& Su 2009, Shwab et al. 2014, Silva et al. 2014). Recently, fatal toxoplasmosis cases caused by atypical T. gondii, in valley quail (Callipepla californica) (Casagrande et al. 2015) and an outbreak in chickens (Vielmo et al. 2019) have been reported in Rio Grande do Sul (Brazil). An atypical genotype also seems to be responsible for the recent largest Brazilian outbreak of human toxoplasmosis in Santa Maria city (Minuzzi et al. 2020). Moreover, atypical genotypes have been reported in primates in Argentina (Pardini et al. 2015).

Sarcocystis spp. DNA was detected in four animals, as confirmed by blastn of the amplified fragment of the $18 \mathrm{~S}$ rRNA gene. At least two different species of Sarcocystis were detected. Sequencing results from Animals 1, 2, and 3 showed 99.4\% similarity with $S$. gigantia and Animal 6 showed 99.3\% similarity with $S$. neurona (Table 2). The alignment of the sequences clearly indicated the difference in size and composition sequence of the Animal 6 sequence and the others (76\% identity) (Fig.1). The 18S rRNA was previously confirmed as a powerful tool for species-specific differentiation of the ovine Sarcocystis species (Heckeroth \& Tenter 1999). Thus, we can state the presence of S. gigantia and S. neurona or very closely related species infecting $A$. guariba clamitans.

Sarcocystis spp. have already been detected in many wildlife species, and primates may serve as both intermediate and definitive hosts, depending on the species of Sarcocystis. Several studies have reported Sarcocystis spp. cysts found in primates (Hernández-Jáuregui et al. 1983, Mandour 1969, Karr \& Wong 1975, Mehlhorn \& Heydorn 1978, Kan et al. 1979, Kimura et al. 1987, Lane et al. 1998, Yang et al. 2005) however, to the best of our knowledge, this is the first report of Sarcocystis spp. infection in primates in Brazil.

Felids are the definitive hosts of S. gigantea, and the known intermediate hosts are small ruminants (Levine \& Tadros 1980); therefore, this is the first report of molecular detection of this species in primates. Macroscopic cysts of S. gigantea were previously detected in sheep in southern Brazil (Minuzzi et al. 2019) confirming the circulation of this protozoan in the region. In our study, S. gigantea DNA was detected in three animals but no injuries or macrocysts were found during necropsy.

Molecular analysis confirmed $S$. neurona in one animal. Didelphis sp. opossums are the definitive hosts of $S$. neurona, and several intermediate and/or accidental hosts are known, such as domestic cats, raccoons, seals, otters, armadillo and horses (Elsheikha 2009). In horses, it causes myeloencephalitis; this condition has also been reported in a rhesus monkey (Klumpp et al. 1994). Positive serology for S. neurona has also been reported in other primates (Yabsley et al. 2007).

Alouatta spp. are herbivores, their diet is basically composed of leaves, fruits, and flowers (Bicca-Marques \& CalegaroMarques 1994); thus, they become infected by ingesting oocysts present in water or food contaminated with definitive host feces. Additionally, geophagy has already been reported in these animals (Bicca-Marques \& Calegaro-Marques 1994), and this habit can increase the contact of animals with feces contaminated with oocysts. It is important to note that the animals from this study lived in a wild fauna maintainer, in which there were also several other species of animals, including wild felids. This environment might have provided the source of infection for brown howler monkeys.

The natural habitat of howler monkeys is fragmented and as cities have expanded, contact between these animals and humans has increased which contributes to the transmission of many diseases (Wolfe et al. 1998). Toxoplasmosis and sarcocystosis are zoonoses and our results suggest that brown howler monkeys in this region may serve as reservoirs for Apicomplexa. Therefore, studies focused on the presence and consequences of these protozoa in primates are important to understand the role of brown howler monkeys in the epidemiology of T. gondii, N. caninum and Sarcocystis spp.

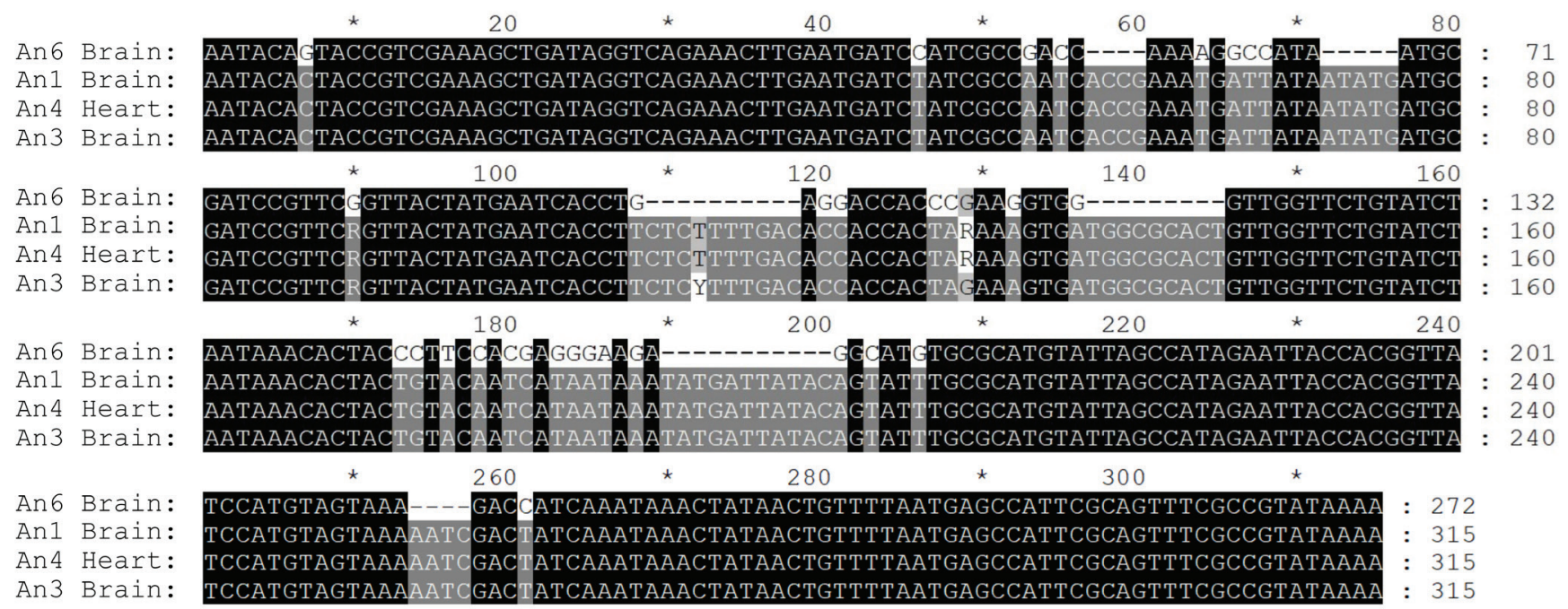

Fig.1. Alignment of Sarcocystis spp. sequences amplified from different tissue samples of brown howler monkey (Alouatta guariba clamitans) visualized in Genedoc 2.7. The order of samples is: Animal 6/ brain, Animal 1/brain, Animal 2/heart, and Animal 3/brain. Every 10 positions in alignment are shown by the number or * and black shade indicates identical nucleotides in all sequences. Polymorphic positions were identified in the sequences from Animals 1 and 2 (position 90, R = A or G; position 129, R=A or G) and Animal 3 (position 90, R = A or G; position 112, Y = C or T). 


\section{CONCLUSIONS}

Our analyses detected the presence of Sarcocystis spp. and Toxoplasma gondii DNA in samples of brown howler monkeys from the Central Region of Rio Grande do Sul. Even with the small sample size and the lack of information about the animal's history, our findings are relevant because they confirm the role of brown howler monkeys as hosts of protozoa with zoonotic potential and reinforce the circulation of atypical T. gondii genotypes in southern Brazil.

Further studies should be conducted to confirm the epidemiological role of Alouatta guariba clamitans in the life cycle of these protozoans.

Conflict of interest statement.- The authors declare that they have no conflict of interest.

\section{REFERENCES}

Adl S.M., Leander B.S., Simpson A.G.B., Archibald J.M., Anderson O.R., Bass D., Bowser S.S., Brugerolle G., Farmer M.A., Karpov S., Kolisko M., Lane C.E., Lodge D.J., Mann D.G., Meisterfeld R., Mendoza L., Moestrup Ø., MozleyStandridge S.E., Smirnov A.V. \& Spiegel F. 2007. Diversity, nomenclature, and taxonomy of protists. Syst. Biol. 56(4):684-689. <https://dx.doi. org/10.1080/10635150701494127><PMid:17661235>

Barr B.C., Conrad P.A., Sverlow K.W., Tarantal A.F \& Hendrickx A.G. 1994. Experimental fetal and transplacental Neospora infection in the nonhuman primate. Lab. Invest. 71(2):236-242. <PMid:8078303>

Bicca-Marques J.C. \& Calegaro-Marques C. 1994. Feeding behavior of the black howler monkey (Alouatta caraya) in a seminatural forest. Acta Biol. Leopoldensia 16(2):69-84.

Casagrande R.A., Pena H.F.J., Cabral A.D., Rolim V.M., Oliveira L.G.S., Boabaid F.M., Wouters A.T.B., Wouters F., Cruz C.E.F. \& Driemeier D. 2015. Fatal systemic toxoplasmosis in Valley quail (Callipepla californica). Int. J. Parasitol. Parasites Wildl. 4(2):264-267. <https://dx.doi.org/10.1016/j. ijppaw.2015.04.003 > <PMid:26101744>

Costa T.L.C., Iglesias G.A., Rosa J.M.A., Bento H.J., Rondelli L.A.S., Furlan F., Morgado T.O., Dutra V. \& Corrêa S.H.R. 2018. Detecção molecular de Neospora caninum em macaco-da-noite (Aotus azarae) de vida livre no estado do Mato Grosso: relato de caso. Arq. Bras. Med. Vet. Zootec. 70(4):1227-1232. <https://dx.doi.org/10.1590/1678-4162-9900>

Cresti S., Ciacci C., Donati E., Giordano I., Tordini G. \& Barberi A. 2001. Evaluation of PCR methods for 5S-rDNA and p30 genes to detect Toxoplasma gondii in blood and other clinical samples. New Microbiol. 24(2):171-174. <PMid:11346301>

Dubey J.P. \& Jones J.L. 2008. Toxoplasma gondii infection in humans and animals in the United States. Int. J. Parasitol. 38(11):1257-1278. <https://dx.doi.org/10.1016/j.ijpara.2008.03.007> <PMid:18508057>

Dubey J.P. \& Lindsay D.S. 1996. A review of Neospora caninum and neosporosis. Vet. Parasitol. 67(1/2):1-59. <https://dx.doi.org/10.1016/ s0304-4017(96)01035-7><PMid:9011014>

Dubey J.P. \& Su C. 2009. Population biology of Toxoplasma gondii: what's out and where did they come from. Mem. Inst. Oswaldo Cruz 104(2):190-195. <https://dx.doi.org/10.1590/s0074-02762009000200011><PMid:19430643>

Dubey J.P. 1986. Toxoplasmosis. J. Am. Vet. Med. Assoc. 189(2):166-170. $<$ PMid:3528098>

Edgar R.C. 2004. MUSCLE: multiple sequence alignment with high accuracy and high throughput. Nucleic Acids Res. 32(5):1792-1797.<https://dx.doi. org/10.1093/nar/gkh340><PMid:15034147>

Elsheikha H.M. 2009. Has Sarcocystis neurona Dubey et al., 1991 (Sporozoa: Apicomplexa: Sarcocystidae) cospeciated with its intermediate hosts? Vet Parasitol.163(6):307-314. <https://dx.doi.org/10.1016/j.vetpar.2009.03.019> <PMid:19375231>
Epiphanio S., Sinhorini I.L. \& Catão-Dias J.L. 2003 Pathology of toxoplasmosis in captive new world primates. J. Comp. Pathol. 129(2/3):196-204. <https://dx.doi.org/10.1016/s0021-9975(03)00035-5><PMid:12921726>

Heckeroth A.R. \& Tenter A.M. 1999. Development and validation of speciesspecific nested PCRs for diagnosis of acute sarcocystiosis in sheep. Int. J. Parasitol. 29(8):1331-1349. <https://dx.doi.org/10.1016/s00207519(99)00111-3><PMid:10576582>

Hernández-Jáuregui P., Silva-Lemoine E. \& Girón-Rojas H. 1983. A case of sarcocystic myocarditis in a rhesus monkey. Light and electron microscopic study. Arch. Invest. Med., Mexico, 14(2):139-144. <PMid:6416199>

Ho M.S., Barr B.C., Tarantal A.F., Lai L.T., Hendrickx A.G., Marsh A.E., Sverlow K.W., Packham A.E. \& Conrad P.A. 1997. Detection of Neospora from tissues of experimentally infected rhesus macaques by PCR and specific DNA probe hybridization. J. Clin. Microbiol. 35(7):1740-1745.<https://dx.doi org/10.1128/jcm.35.7.1740-1745.1997><PMid:9196184>

Homan W.L., Vercammen M., Braekeleer J. \& Verschueren H. 2000. Identification of a 200 - to 300-fold repetitive 529 bp DNA fragment in Toxoplasma gondii, and its use for diagnostic and quantitative PCR. Int. J. Parasitol. 30(1):69-75. <https://dx.doi.org/10.1016/s0020-7519(99)00170-8><PMid:10675747>

Johnson M., Zaretskaya I., Raytselis Y., Merezhuk Y., McGinnis S. \& Madden T.L. 2008. NCBI BLAST: a better web interface. Nucleic Acids Res. 36(Web Server issue):W5-W9. <https://dx.doi.org/10.1093/nar/gkn201> <PMid:18440982>

Jones C.D., Okhravi N., Adamson P., Tasker S. \& Lightman S. 2000. Comparison of PCR detection methods for B1, P30, and 18S rDNA genes of T. gondii in aqueous humor. Investig. Ophthalmol. Vis. Sci. 41(3):634-644. <PMid:10711675>

Kan S.P., Prathap K. \& Dissanaike A.S. 1979. Light and electron microstructure of a Sarcocystis sp. from the Malaysian long-tailed monkey, Macaca fascicularis Am. J. Trop. Med. Hyg. 28(4):634-642. <PMid:111569>

Karr S.L. \& Wong M.M. 1975. A survey of Sarcocystis in nonhuman primates. Lab. Anim. Sci. 25(5):641-645. <PMid:810620>

Kimura T., Ito J., Suzuki M. \& Inokuchi S. 1987. Sarcocystis found in the skeletal muscle of common squirrel monkeys. Primates 28:247-255. $<$ https://dx.doi.org/10.1007/BF02382574>

Klumpp S.A., Anderson D.C., McClure H.M. \& Dubey J.P. 1994. Encephalomyelitis due to a Sarcocystis neurona-like protozoan in a rhesus monkey (Macaca mulatta) infected with simian immunodeficiency virus. Am. J. Trop. Med. Hyg. 51(3):332-338. <https://dx.doi.org/10.4269/ajtmh.1994.51.332> <PMid:7943553>

Lane J.H., Mansfield K.G., Jackson L.R., Diters R.W., Lin K.C., MacKey J.J. \& Sasseville V.G. 1998. Acute fulminant sarcocystosis in a captiveborn rhesus macaque. Vet. Pathol. 35(6):499-505. <https://dx.doi. org/10.1177/030098589803500604> <PMid:9823591>

Levine N.D. \& Tadros W. 1980. Named species and hosts of Sarcocystis (Protozoa: Apicomplexa: Sarcocystidae). Syst. Parasitol. 2:41-59. <https:// dx.doi.org/10.1007/BF00015094>

Mandour A.M. 1969. Sarcocystis nesbitti n. sp. from the rhesus monkey. J. Protozool.16(2):353-254.<https://dx.doi.org/10.1111/j.1550-7408.1969. tb02281.x> <PMid:4978784>

Mehlhorn H. \& Heydorn A.O. 1978. The sarcosporidia (Protozoa, Sporozoa): life cycle and fine structure. Adv. Parasitol. 16:43-91. <https://dx.doi org/10.1016/s0065-308x(08)60572-2> <PMid:103377>

Meireles C.M., Czelusniak J., Ferrari S.F., Schneider M.P.C. \& Goodman M. 1999. Phylogenetic relationships among brazilian howler monkeys, genus Alouatta (Platyrrhini, Atelidae), based on $\gamma^{1}$-globin pseudogene sequences. Genet. Mol. Biol.22(3)337-344.<https://dx.doi.org/10.1590/S1415-47571999000300009>

Minuzzi C.E., Cezar A.S., Bräunig P., Portella L.P., Rodrigues F.S., Sangioni L.A. \& Vogel F.S.F. 2019. Occurrence of Sarcocystis gigantea macrocysts and high frequency of $S$. tenella microcysts in sheep from southern Brazil. Vet. Parasitol. Reg. Stud. Rep. 15:100256. <https://dx.doi.org/10.1016/j. vprsr.2018.12.002><PMid:30929933> 
Minuzzi C.E., Portella L.P., Bräunig P., Sangioni L.A., Ludwig A., Ramos L.S., Pacheco L., Silva C.R., Pacheco F.C., Menegolla I.A., Farinha L.B., Kist P.P., Breganó R.M., Nino B.S.L., Martins F.D.C., Monica T.C., Ferreira F.P., Britto I., Signori A., Medici K.C., Freire R.L., Garcia J.L., Navarro I.T., Difante C.M. \& Vogel F.S.F. 2020. Isolation and molecular characterization of Toxoplasma gondii from placental tissues of pregnant women who received toxoplasmosis treatment during an outbreak in southern Brazil. PLoS One 15(1):e0228442. <https://dx.doi.org/10.1371/journal.pone.0228442><PMid:31999785>

Molina C.V., Catão-Dias J.L., Ferreira Neto J.S., Vasconcellos S.A., Gennari S.M., Valle R.D., Souza G.O., Morais Z.M., Vitaliano S.N., Strefezzi R.F. \& Bueno M.G. 2014. Sero-epidemiological survey for brucellosis, leptospirosis, and toxoplasmosis in free-ranging Alouatta caraya and Callithrix penicillata from São Paulo State, Brazil. J. Med. Primatol. 43(3):197-201. <https://dx.doi.org/10.1111/jmp.12112> <PMid:24646216>

Moré G., Abrahamovich P., Jurado S., Bacigalupe D., Marin J.C., Rambeaud M., Venturini L. \& Venturini M.C. 2011. Prevalence of Sarcocystis spp. in Argentinean cattle. Vet. Parasitol. 177(1/2):162-165. <https://dx.doi. org/10.1016/j.vetpar.2010.11.036><PMid:21168276>

Nery-Guimarães F. \& Franken A.J. 1971. Toxoplasmose em primatas não humanos: II - Tentativas de infecções experimentais em Macacca mulatta, Cebus apella e Callithrix jacchus; e pesquisa de anticorpos em várias espécies de platyrrhinus. Mem. Inst. Oswaldo Cruz. 69(2):97-111. <https://dx.doi. org/10.1590/S0074-02761971000200005><PMid:5002530>

Nicholas K.B., Nicholas H.B.J. \& Deerfield D.W.I. 1997. Genedoc: a tool for editing and annotating multiple sequence alignments. Embnewnews 4:14.

Nunn C.L. \& Altizer S.M. 2005. The global mammal parasite database: an online resource for infectious disease records in wild primates. Evol. Anthropol. 14(1):1-2. <https://dx.doi.org/10.1002/evan.20041>

Pardini L., Dellarupe A., Bacigalupe D., Quiroga M.A., Moré G., Rambeaud M., Basso W., Unzaga J.M., Schares G. \& Venturini M.C. 2015. Isolation and molecular characterization of Toxoplasma gondii in a colony of captive blackcapped squirrel monkeys (Saimiri boliviensis). Parasitol. Int. 64(6):587-590. <https://dx.doi.org/10.1016/j.parint.2015.08.009><PMid:26299363>

Pena H.F.J, Gennari S.M., Dubey J.P. \& Su C. 2008. Population structure and mouse-virulence of Toxoplasma gondii in Brazil. Int. J. Parasitol. 38(5):561569. <https://dx.doi.org/10.1016/j.ijpara.2007.09.004><PMid:17963770>

Santos S.V., Strefezzi R.F., Pissinatti A., Kanamura C.T., Takakura C.F.H., Duarte M.I.S. \& Catao-Dias J.L. 2014. Detection of Toxoplasma gondii in two southern Wooly spider monkeys (Brachyteles arachnoides Geoffroy, 1806) from the Rio de Janeiro primate center, Brazil. J. Med. Primatol. 43(2):125-129. <https://dx.doi.org/10.1111/jmp.12093><PMid:24757733>

Shwab E., Zhu X-Q., Majumdar D., Pena H.F.J., Gennari S.M., Dubey J.P. \& Su C. 2014. Geographical patterns of Toxoplasma gondii genetic diversity revealed by multilocus PCR-RFLP genotyping. Parasitology 141(4):453-461. <https://dx.doi.org/10.1017/S0031182013001844><PMid:24477076>

Sibley D.L. 2003. Recent origins among ancient parasites. Vet. Parasitol. 115(2):185-198. <https://dx.doi.org/10.1016/s0304-4017(03)00206-1> $<$ PMid:12878422>

Silva A.V., Moraes G.B.S., Langoni H. \& Bagagli E. 2006. Study of Toxoplasma infection in Brazilian wild mammals: serological evidence in Dasypus novemcinctus Linnaeus, 1758 and Euphractus sexcinctus Wagler, 1830. Vet. Parasitol.135(1):81-83.<https://dx.doi.org/10.1016/j.vetpar.2005.08.013> <PMid:16188389>

Silva L.A., Andrade R.O., Carneiro A.C.A.V. \& Vitor R.W.A. 2014. Overlapping Toxoplasma gondii genotypes circulating in domestic animals and humans in Southeastern Brazil. PLoS One 9(2):e90237.<https://dx.doi.org/10.1371/ journal.pone.0090237><PMid:24587295>

Silva R.C., Su C. \& Langoni H. 2009. First identification of Sarcocystis tenella (Railliet, 1886) Moulé, 1886 (Protozoa: Apicomplexa) by PCR in naturally infected sheep from Brazil. Vet. Parasitol. 165(3/4):332-336. <https://dx.doi.org/10.1016/j.vetpar.2009.07.016><PMid:19647370>

Solórzano-García B. \& Pérez-Ponce de León G. 2018. Parasites of neotropical primates: a review. Int. J. Primatol. 39:155-182. <https://dx.doi.org/10.1007/ s10764-018-0031-0>

Staden R., Beal K.F. \& Bonfield J.K. 2000. The Staden package, 1998. Methods Mol. Biol. 132:115-130. <https://dx.doi.org/10.1385/1-59259-192-2:115> <PMid:10547834>

Su C., Shwab E.K., Zhou P., Zhu X.Q. \& Dubey J.P. 2010. Moving towards an integrated approach to molecular detection and identification of Toxoplasma gondii. Parasitology 137(1):1-11. <https://dx.doi.org/10.1017/ S0031182009991065><PMid:19765337>

Su C., Zhang X. \& Dubey J.P. 2006. Genotyping of Toxoplasma gondii by multilocus PCR-RFLP markers: a high resolution and simple method for identification of parasites. Int. J. Parasitol. 36(7):841-848. <https://dx.doi. org/10.1016/j.ijpara.2006.03.003><PMid:16643922>

Vielmo A., Pena H.F.J., Panziera W., Bianchi R.M., Lorenzo C., Oliveira S., Alves B.F., Gennari S.M., Pavarini S.P., Barros C.S.L. \& Driemeier D. 2019. Outbreak of toxoplasmosis in a flock of domestic chickens (Gallus gallus domesticus) and guinea fowl (Numida meleagris). Parasitol. Res. 118(3):991-997. <https://dx.doi.org/10.1007/s00436-019-06233-w><PMid:30725180>

Wolfe N.D., Escalante A.A., Karesh W.B., Kilbourn A., Spielman A. \& Lal A.A. 1998. Wild primate populations in emerging infectious disease research: the missing link? Emerg. Infect. Dis. 4(2):149-158. <https://dx.doi. org/10.3201/eid0402.980202> <PMid:9621185>

Yabsley M.J., Jordan C.N., Mitchell S.M., Norton T.M. \& Lindsay D.S. 2007. Seroprevalence of Toxoplasma gondii, Sarcocystis neurona, and Encephalitozoon cuniculi in three species of lemurs from St. Catherines Island, GA, USA. Vet. Parasitol.144(1/2):28-32. <https://dx.doi.org/10.1016/j.vetpar.2006.09.020> $<$ PMid:17052854>

Yamage M., Flechtner O. \& Gottstein B. 1996. Neospora caninum: specific oligonucleotide primers for the detection of brain "cyst" DNA of experimentally infected nude mice by the polymerase chain reaction (PCR). J. Parasitol. 82(2):272-279. <https://dx.doi.org/10.2307/3284160><PMid:8604096>

Yang Z-.Q., Wei C-.G., Zen J-S., Song J-.L., Zuo Y-.X., He Y-.S., Zhang H-.F., Attwood S.W., Chen X-.W., Yang G-.C., Zhou X., Quan X., Li C-.Y., Han D., Liu A-W. \& Lin P. 2005. A taxonomic re-appraisal of Sarcocystis nesbitti (Protozoa: Sarcocystidae) from the monkey Macaca fascicularis in Yunnan, PR China. Parasitol. Int. 54(1):75-81. <https://dx.doi.org/10.1016/j. parint.2004.12.004><PMid:15710555> 